EMPI,OYEE OWNERSHIP, CONTROI, OF PENSION FUNDS, AND INDUSTRIAL DEMOCRACY IN THE UNITED STATES

\title{
Tim Knapp
}

Universily of Kansas

Mid-American Review of Sociology, 1988, Vol. XIII, No. 1:3-20

The ongoing transformation of the American economy has resulted in a decline in material well-being for most workers, and has brought a host of problems to communities across the country. (iiven these developments, a growing number of workers, labor representatives, and community leaders are advocating employee ownership of businesses as a possible means to reduce the negative consequences of this Iransfomnation. An increase in employce ownership presents both opportunities and problems for advocates of industrial democracy in America. This paper discusses some of those problems and opportunities, including the disjuncture between employee ownership and self-management, the uses and abuses of Employee Srock Ownership Plans, and the control of pension funds. The analysis concludes with several proposals to utilize employee ownership as a tool for the advancement of industrial democracy in the United States.

\section{INTRODUCTION}

The American economy is in the midst of a major transformation. Several million jobs in manufacturing have been lost since the late 1970 s. Public sector employment growth has slowed significantly, and joh creation in the service sector has become concentrated in a relatively small number of low-paying industries. As William Foote Whyte notes, the current restructuring is "as significant as the Industrial Revolution in the last century. This transition will affect the organization of work, relationships between management and labor,... and, in some cases, the ownership of private business enterprises" (Whyte, Hammer, Meek, Nelson, and Stern, 1983:v). Unfortunately, advocates of industrial democracy have paid insufficient attention to the political responses to economic restructuring. This paper begins to fill that gap by evaluating the movement toward employee ownership as one means of advancing industrial democracy in the U.S. ${ }^{1}$

Despite popular accounts of an American renewal, it is clear that the majority of employees in today's deindustrialized job market are not doing as well as workers in the late 1960s or early 1970s, the latter years of the affluent society era (Knapp, 1988a). For example, average weekly earnings of production and nonsupervisory personnel rose 61 percent between 1947 and 1972 . However, as hourly compensation and the number of hours worked per week declined, the average weekly paycheck fell by nearly 15 percent between 1973 and 1987 (Bureau of Labor Statistics, 1985, 1987, 1988). This translates into a decline of mean annual earnings of nearly $\$ 1,500$ (Bureau of the Census, 1985, 1987:20). With the exception of the deep recession of 1982, average weekly earnings in 1987 were lower than at any time since 1962

In addition to lower pay, today's workers receive fewer nonwage benefits such as private pensions and employer-sponsored health care plans. Employer con- 
trihutions to private pensions peaked in 1977 , and have declined since then. By 1984, the average employer pension payment per employee was 2 percent lower than in 1971 (adjusted from data in Chamber of Commerce, 1985:iii; see also The Wall Street Jonimal, 1987a). Of the nearly 37 million persons without health insurance in the United States, approximately 24 million are job holders and their dependents. Paradoxically, the prohlem of inadequate health care coverage has worsened during the current economic expansion, as the number of uninsured workers rose 22 percent between 1982 and 1985 (Anderson and Spear, 1988:5). Other nonwage benefits have also been curtailed in recent years. In its annual survey of benefits, the Chamher of Commerce (1985:5) reported that "significantly smaller proportions of companies reported payments for vacations, holidays, sick leave, and rest periods."

Beyond the reduction in earnings and benefits, the results of economic transformation have rippled outward with adverse consequences for entire comnunities. Many communities have experienced decaying infrastructure, limited provision of social services, and substantial nutmigrations resulting from plant closings and deteriorating employment opportunities (Bluestone and Harrison, 1982 and 1986; Currie, Dunn, and Fogerty, 1985; Harris, 1984; Jacobson and Thomason, 1979; Jaffe, 1986; Owens and Clark, 1984; Peet, 1984; Sheets, Smith, and Voytek, 1985; and Stillman, 1978).

In response to continued problems resulting from economic transformation, a growing number of firms are heing established or reorganized as employee-owned and in some cases, worker-controlled ${ }^{3}$ enterprises. The remainder of this paper analyzes issues related to this emergent trend. Section one broadly defines employee ownership and explores the economic viahility of worker-owned organizations. The (non)relationship between ownership and control is discussed in section two, leading to an analysis in section three of Employee Stock Ownership Plans. Section four addresses the use of pension funds to finance worker-owned ventures. Finally, the conclusion ties the various issues together into an agenda for capitalizing on the rise in employee ownership in order to advance industrial democracy. The normative elements of the conclusion in no way imply a biased analysis of the issues addressed here. My approach has followed that of C. Wright Mills who once said, "I have tried to be- objective. I do not claim to be detached" (in Blumberg, 1968:viii).

\section{EMPLOYEE OWNERSHIP \\ AND THE QUESTION OF ECONOMIC VIABILITY}

Employee ownership in the United States is a diverse phenomena, ranging from producer cooperatives with all members having equal earnings and equal voting rights, to Employee Stock Ownership Plans with substantial income differentials and no voting rights for plan members. Only a very general definition can encompass this range of organizational and procedural forms. The National Center for Employee Ownership (NCEO) broadly defines worker ownership as "a plan in which most of a company's employees own at least some stock in their company, even if they cannot vote it, and even if they cannot sell it till they leave the company or retire" (Rosen, Klein, and Young, 1986:14). Using this definition, the NCEO estimated that in 1986 over 8,000 firms had worker ownership plans; 1,000 firms were 100 percent employee owned; and over 11 million employees, or ahout 8 percent of the labor force, were worker-owners (Quarrey, Blasi, and Rosen, 1986:viii). Barring legislative changes, continued growth in the number of worker ownership plans is expected.

One of the most basic questions concerning employee ownership is whether worker-owned firms are economically viable. Although the body of research is not as large as one would like, early studies suggest that employee-owned companies are at least as economically viable as conventionally owned and organized enterprises. Four aspects of the performance of employee-owned companies support this conclusion.

First, employee-owned firms are highly productive. One analysis of 134 employee-owned firms found that these companies had annual productivity growth rates one and one-half times greater than the average of comparable conventional husinesses (Marsh and Mc.Allister, 1981:614). This result is consistent with a number of other studies which have indicated higher levels of productivity in worker-owned firms (Bernstein, 1976:18-19; Blumherg, 1968:78-81; Bowles, Gordon, and Weisskopf, 1984:122-149; Carnoy and Shearer, 1980:170-172 and 1983:72-75; Levin, 1982). The major productivity advantages of employee-owned firms lie in greater human effort, and in the reduction of material waste. Employees work harder when they know that some of the fruits of those ${ }^{4}$ efforts (beyond wages or salaries) will accrue to them. As one employee of a workerowned firm explained to Conte, Tannenbaum, and McCullock (1981:50), "well, now everyhody is more or less making money for themselves. It's their work, not just the company's. Before the money was going into somebody else's pocket. Now it's our own." Employee-owners also have a stake in reducing material inputs. Another worker noted, "everybody is not so willing to throw away a part anymore which is one of the first signs they cared for the company. Scrap is held to a minimum" (Conte et al., 1981:43). The productivity of worker-owned firms is indeed impressive, considering that the overall economy is experiencing a declining rate of productivity growth.

Second, employee-owned enterprises also generate a larger number of new johs than do their traditionally organized counterparts. A 1983 NCEO study found that companies which were majority owned by their employees created three times more net new jobs than comparable conventional firms (Rosen and Klein, 1983) This is partly due to worker-owned firms not reducing employment in downturns as much as conventional firms (Tannenbaum, Cook, and Lohmann, 1984). However, higher job creation performance also appears to result from the strong produc-tivity, high rates of product and process innovations, and technological adaptiveness of employee-owned companies (Bradley and Gelb, 1985:125-128).

Third, worker-owned firms appear to be administratively "efficient." Some analysts argue the opposite, that worker-owned firms are less administratively efficient than traditional firms because employee ownership is sometimes related to a reduction of hierarchical authority (Williamson, 1975). However, such an argument is not very convincing. While employee-owned firms may flatten the "control hierarchy" (a reduction in foremen and supervisors for example), worker ownership has not been shown to impair the functioning of "coordination hierarchies" (Horvat, 1982:189). The plywood cooperatives of the Pacific Northwest are an example. Hierarchical control has been largely replaced by informal 
controls exercised through peer pressure and by formal controls based on democratically established performance criteria and disciplinary procedures Operational administration is accomplished by an elected and accountable coordination hierarchy (Berman, 1982; Zwerdling, 1980:95-104). There is no evidence or logical argument which suggests a necessary loss of administrative effectiveness in employee-owned firms. Therefore, the charge that worker-owned companies are "inefficient" remains based more on ideology than on economics (Knapp, 1988h).

Fourth, worker-owned companies may be more profitable than their conventionally-organized counterparts, and profitability remains the hottom line in the conventional calculus of economic viability (Conte et al., 1981:20-27). For example a study for the New York Stock Exchange of companies which were at least 10 percent employee owned found that these firms had, on average, larger net operating margins, higher stock share values, and greater return to equity than matched non-employee owned companies (Rosen et al., 1986:50)

Although much more research is needed before definitive conclusions can be drawn, existing studies of the productivity, job creation capacity, administrative effectiveness, and profitability of worker-owned firms suggest that these companies are at least as economically viable as are traditionally owned and managed enterprises. This is the case even though worker-owned companies often

have greater difficulty than conventional firms in securing financial, legal, and technical support services.

But the traditional methods of evaluating the economic "success" of firms are not adequate when analyzing employee-owned enterprises as a means of democratically managing economic restructuring. To accomplish this, the issue of broadened control of business decision-making must be addressed.

\section{OWNERSHIP AND CONTROL OF ENTERPRISES}

Ownership of productive property has traditionally heen viewed as a "bundle" of rights. This bundle includes rights of usus, fructus, and abusus, or the rights of usage, appropriation of benefit, and disposal of a thing (Russell, 1985:2; Horvat, 1982:235). However, in the-majority of employee-owned companies this collection of rights is broken up because the rights to control the use and abuse of productive assets are not granted to workers. For example, only 21 percent of companies with Employee Stock Ownership Plans (ESOPs) grant full voting rights to plan participants or their representatives (Marsh and McAllister, 5 1981:593 -594). Worker-owners in the United States are "part owners" in two senses. First they usually own only part of the enterprise. Second, this grants them only part of the property rights associated with ownership. It is thus only an exaggeration of a very real condition when Kuttner (1987:16) editorializes that in employee-owned companies, "workers ordinarily end up with about as much influence in the management of the firm as Soviet workers have in managing the Kremlin."

The disassociation of control rights from the ownership of productive property raises several questions concerning the effectiveness of employee ownership as a means to democratize the management of economic 6 transformation.

A fundamental question is whether or not workers want more control over business decision making. Bradley and Gelb (1985:126) report that most workers are "reluctant managers," and there is a general perception that workers are indifferent towards increased participation in company decisions. However, a number of studies have found evidence of a lateni desire for increased control among workers (see Bernstein, 1976; Blumberg, 1968; Conte et al., 1981; DeWitt, 1980; Jones and Svejnar, 1982; Lichtenstein, 1986; Whyte et al., 1983).

The inconsistent findings of research on employee attitudes toward ownership might be clarified by analyzing historical shifts in the experiences of American workers. The vast majority of today's workers have never experienced ownership of productive property. They have not learned that control is a normal, and desirahle, component of such ownership. What they have experienced, and grown accustomed to, is a lack of control in the workplace. In the years following World War II, a general "accord" was struck between business and organized labor whereby participation in business decisions was traded for a larger share of profits (Gordon et al., 1982). As long as profits and wages rose, employees were relatively content to sacrifice control in the workplace for the opportunity to own a growing array of consumer durables and leisure items. But in contrast to the 1950s and $1960 \mathrm{~s}$, the majority of workers today are no longer experiencing rising wages. Furthermore, a growing number of workers (approximately 8 percent of the labor force) are experiencing employee ownership. Given these experiential changes, an interesting question arises: Can employee ownership increase workers' desire to control enterprises?

While the evidence is somewhat inconsistent, it appears that the experience of ownership does heighten workers' interest in control. The positive relationship hetween the experience of ownership and desire for control can be explained in several ways. First, workers have experienced the complete hundle of property rights in the ownership of nonproductive assets such as their homes, automnhiles, and consumer durables. They have enjoyed the right to control the use and abuse of what they have owned. When they become "owners" of productive property, many workers do not understand, and come to resent, the disassociation of control from other property rights. Second, most employee ownership plans are accompanied by very modest worker participation in task-related decisions and in the coordination of social functions. As Mason (1982), Pateman (1970), and others have suggested, there is an educational value in even such limited experiences of participation. The experience of efficacy in controlling small matters both increases workers' desire to influence decisions currently reserved for managers, and increases their ability ${ }^{7}$ to shoulder greater decision-making responsibility.

As the interest of workers in controlling firms grows, there will likely he increased opportunities to put those desires into practice. This is because the majority of worker ownership plans are designed so that the proportion of the company owned by employees increases over time (Rosen et al., 1986:43-44), and because worker control should expand somewhat in conjunction with the increasing proportion of ${ }^{8}$ equity owned by employees (Conte et al., 1981:55).

Opponents of employee ownership are justified in their criticisms of the disjunction between control and ownership. However, any degree of employee ownership constitutes an inroad into corporate capitalism's present denial of both ownership and control to workers. As Quarrey et al. (1986:23) note, even if only approximately $\mathbf{4 0 0}$ companies out of 8,000 employee-owned enterprises combine control with ownership, "at least that is $\mathbf{4 0 0}$ more than are controlled by workers 
but not owned by them." And, as Rosen et al. (1986:200) point out, "the step from ownership to ownership and control... is shorter than the step from neither to both." Employee ownership can thus be viewed as a legitimate means of expanding worker control.

An analysis of ESOPs, the major form of employee ownership, will provide insights into why worker ownership has not yet transformed the relations of production of corporate capitalism.

\section{ESOPS: RIPOFF OR REVOLUTION?}

Of the 8,000 to 9,000 employee-nwned firms in the United States, approximately 7,0M have Employee Stock Ownership Plans. In the typical ESOP, workers own about one third of the stock, with employees heing majority shareholders in 10-15 percent of the plans (Rosen et al., 1986:43). Although ESOPs vary considerahly, the general elements of the plans are similar. Companies set up a trust fund for their employees and then contribute cash for stock purchases, or stock itself, to the trust. The shares are allocated to accounts for individual workers, who acquire rights to those shares as they become vested. Employees receive their shares (or the current value of the shares) when they retire or leave the company.

Designed by the attorney and economist Louis Kelso, the first ESOP was established in the United States in 1956. Kelso maintained that a broader distribution of wealth would remedy many of the problems of advanced capitalism. However, few capitalists were willing to share the wealth, and Kelso's recommendations received scant acceptance until Congress provided legislative authority and tax benefits for ESOPs in the Employee Retirement Income Security Act (ERISA) of 1974. Since ERISA, the number of ESOPs has nearly tripled, and provisions of the 1984 Deficit Reduction Act have added further incentives for ${ }^{9}$ companies to estahlish this form of employee ownership.

ESOPs are very flexible instruments which have been used for a variety of purposes. Estimates are that about one third of the plans are established to provide a market for a retiring owner, one quarter are used to horrow money for the firm on a favorable tax basis, another third are set up to provide "second income" benefits to employees, and about 10 percent of. ES()Ps involve distress buyouts and stock-for-concession deals (Rosen et al., 1986:44). Unfortunately, the variability of ESOPs has allowed a number of abuses to occur, intensifying the debate over the effects of these plans on workers.

Some analysts, such as Kuttner (1987), maintain that ESOPs are usually a "con" for workers, and there are certainly cases which support this view. One particularly egregious example of an ESOP "ripoff" is the textile manufacturer Dan River Inc Fearing layoffs resulting from a takeover of the company by Carl Icahn, workers voted in 1983 to terminate their pension plan in order to establish an ESOP (whose trustees then voted with management to avoid the hostile takeover). At Dan River, the ESOP failed to provide workers with either workplace control, job security, or financial gains. By 1985 the employees did not have even token democracy in the workplace, and the labor force had been cut by one third. Furthermore, due to a division of stock into two classes distributed separately to managers and workers, management was reaping the lion's share of financial benefits. The Dan River plan exemplifies an ESOP which is actually a MESOP, "management enrichment stock ownership plan" (Business Weck, 1985:94, 97).

However, there are also many ESOP success stories. One example is Lowe's, building materials supply company which established a form of ESOP in 1957 The warehouse lahorer retired after 17 years with stock worth $\$ 666,000$. By 1984 warehouse lahorer retired after 17 years with stock worth $\$ 666,000$. By 1984,
Lowe's had created over 50 employee-owner millionaires (Quarrey, et al., 1986: 129-130).

Of course, neither Lowe's or Dan River gives an adequate impression of the Of course, neither Low to ESOPs. Studies of relatively large samples of ESOPs suggest that in the vast majority of cases, these plans are not financial ripoffs for workers. For example, although data on small firms is limited, it (they are retirement benefits are usually not reduced in the new plans (Rosen et al. 1986:29-30). Also, in contrast to the common notion that ES()Ps are estahlished in exchange for wage concessions (Sease, 1985), research indicates that total remuneration in ESOP firms is not lower than industry averages (Quarrey et al., remuiner.

But while it is clear that ESOPs are generally not financial ripoffs for workers, hey clearly have not provided employees with much say in how "their" companies are run. For this reason, ESOPs might be considered political cons for workers. are run. For this reason, ESOPs might be considered political cons for workers. It should not be surprising that this form of employee ownership has not advanced industrial democracy very far since none of the early advocates of ESOPs (such as Kelso, Mortimer Adler, or Russell Longere. However, ESOPs do have the potential to radically alter control relations.

ESOPs are extremely flexible legal instruments, and they can he, and have heen, used to create democratic enterprises (Ellerman, 1985). A contemporary example from the airlines industry reveals the diverse potential of ESOPs. Employees of Eastern Airlines traded wage concessions for approximately 2.5 percent of company stock and a degree of democratization. However, when financial strains continued, Eastern's employee-owners could do nothing to keep financial strains continued, Eastern's employee-owners could the other hand, the pilots of United Airlines are offering to buy United through an ES(-)P leveraged buyout and, in this case, are proposing an employee-managed firm. If the deal goes through, the new company could be democratically run by its work force (Kuttner, 1987).

In brief, ESOPs are generally not financial ripoffs for workers. And, while ESOPs may be a political con as currently structured, these plans have the potential to be an important tool in the democratization of the American economy. As Quarrey et al. (1986:17) point out, "while most ESOPs are not very democratic, many are, and many more workers are in democratic or partly democratic ESOPs many are, and many more workers are in democratic or partly

Though the financial community is beginning to accept ESOPs, the funding of employee-owned and self-managed enterprises remains a crucial issue. One potential source of finance capital is the large and rapidly expanding pool of pension funds. However, the prevailing structure of management of these plans will have to be altered if portions of pension funds are to be used to finance worker owned and self-managed firms. 


\section{MANAGING PENSION INVESTMENTS}

Pension funds have become the largest hlock of finance capital availahle in the United States. Employer-sponsored pensions contained approximately \$1.7 trillion dollars in 1986 (Kosterlitz, 1987:2138; Stemnock, 1987), and total pension fund assets are projected to reach $\$ 4$ trillion by the mid-1990s. Currently, pension funds own approximately one-third of the stock of publicly traded corporations (Heard, 1987:89), and 40 percent of corporate annuities with maturities over one year (Barher, 1982:32). Collectively, pensions "own control of practically every single one of the 1,000 largest industrial corporations in America" (Drucker, 1976:2). For Drucker, this is proof that "pension fund ${ }^{10}$ socialism" has come to America.

Yet, in another sense, workers "own" nothing through their pensions. As mentioned earlier, the control of the use of a thing is an essential element of ownership rights, and workers have little influence over the investments made with "their" pension money. Instead, control over pension funds is concentrated in a relatively small number of financial institutions, with the top 25 firms overseeing $\$ 325$ billion $^{11}$ in pension assets (Munnell, 1983:20).

When assessing the argument that pension monies could he utilized to broaden the management of economic transformation, one fundamental point needs to be made: the retirement income of workers must not be sacrificed in order to democratize the economy. However, democratic control of pensions does not imply a reduction in the level or security of retirement incomes. On the contrary, the poor performance and riskiness of institutionally controlled pension schemes suggest the need for new approaches to the management of pension funds.

A number of studies have shown that pension investments consistently receive returns that are 1 to 2 percent lower than market index averages, and significantly ower than the average performance of mutual funds (Corrigan, 1983:2368. Barber, 1982:34-36). Munnell (1983:21-26) maintains that the poor performance of pension funds results from "institutional factors." Financial institutions frequently entrust pensions to the corporate treasurer, a position that is traditionally a rung in the career ladder for young executives. Knowing that their tenure as treasurer will be brief, aspiring executives apparently do not make maximum return their sole or primary objective. Instead, they also attempt to advance the economic interests of other customers of their firm. The primary means to attain acceptable (rather than maximum) maximum) pension performance while enhancing one's career is to invest pension assets in the ${ }^{12}$ stock of corporate customers of the institution. Fiduciaries maintain that below-average returns are justified because pension investments are more secure in corporate stocks. However, the insecurity of institutionally controlled pensions undermines this rationale.

Even after ERISA, defined-benefit as well as defined-contribution pension schemes are far from secure. The guidelines established by that law are extremely general and an enforcement program for ERISA is "for all practical purposes,... nonexistent at present" (Heard, 1987:99). The primary threat to pension security has heen, and remains, underfunding. According to Kosterlitz (1987:2140), ERISA is inadequate because it "gives companies so much latitude in figuring pension liabilities that unscrupulous companies can grossly underfund plans while staying within the letter of the law." The growing number of defaults on pension liabilities which has overwhelmed the government's Pension Benefit Guarantee Corporation supports Kosterlitz's assessment of underfunding problems (Wall Street Joumal, 1987b).

While underfunding remains the primary prohlem, overfunding can also result in pension instability. When pension assets in defined-benefit plans exceed what is needed to pay henefits accumulated by employees, employers are free to terminale plans and "recapture" the surplus. A growing number of companies have terminated plans in recent years as high interest rates and the bull stock market of 1982 to late-1987 resulted in pension fund surpluses. Among the largest terminations, Occidental Petroleum recovered $\$ 363$ million, and the Great Atlantic \& Pacific Tea Company "grabbed" \$275 million (Brownstein, 1984:568). Unlike Canadian practices which ensure that "excess" earnings remain in the pension fund, the U.S. Lahor Department has ruled that terminating a plan to recapture surplus assets does not violate the "exclusive benefit" provision of ERISA.

A third risk to the security of pensions is the erosion of benefits due to inflation. For example, the average cost-of-living adjustment extended to pension beneficiaries between 1975 and 1979 was equivalent to a one-time increase of 9 percent. Since consumer prices rose 39 percent during the same period, many pensioners suffered a sharp decline in income (Munnell, 1983:27).

Given the poor performance of institutional managers, a number of workers and their representatives have expressed an interest in increasing labor's coutrol of pension funds. As one union administrator explained it:

Our memhers alone have at least $\$ 15$ billion in the pension funds that we have negotiated, although we have no voice in their investment. Now, that's the way we used to want it, but we've realized that we simply can't afford to leave investment of these funds to others. We've learned what's wrong with the way that these funds are used: they're invested mostly in non-union companies, they're not investing them back into our communities where members live and work, they don't put money into anything but 'blue chip' corporations, and they've had a lousy return. As I say, we know what's wrong, but I still worry about what we should be doing.... We don't even

have experts we can rely on,... but 1 guess we have to start somewhere (in Barber, 1982:42-43).

Both the Executive Council and the Industrial Union Department of the American Federation of Labor and Congress of Industrial Organizations puhlished reports in 1980 stressing the need for greater union involvement in the management of pension funds. Lane Kirkland summarized the new sentiment when he noted that without jeopardizing the benefits of present or future retirees, "pension funds should invest to improve the life and working conditions of working men and women. Unions should be in a position to influence the investment of pension funds to better serve the interests of workers" (in Barber, 1982:50).

The performance of jointly controlled, multiemployer, and Taft-Hartley plans suggest that broadened worker control of pensions does not lead to a reduction of the level or security of retirement income. Rather, studies indicate that the security and investment returns for jointly administered plans have been on par with the performance of other ${ }^{13}$. pension funds (Munnell, 1983:28). 
Mid-American Review of Sociology

While jointly controlled plans vary little from other pension systems in terms of performance or security, the investment patterns of some building trades and maritime pensions suggest an important difference. The International Brotherhood of Electrical Workers' national pension fund has over 40 percent of its assets invested in mortgages, and a group of Southern California construction workers pension funds have formed a 'Foundation' which invests ahout $\$ 15$ million monthly in union built structures (Barber, 1982:51). In these, and other examples, plan managers have followed the "double benefit" notion; the idea that pension funds should provide a benefit (steady employment) during one's working life as well as during retirement. To date, there is no evidence from private plans that "double benefit" investment ${ }^{14}$ strategies result in the financial insecurity of pensions.

The preceding analysis suggests that there are no compelling economic reasons why workers should not expand their influence over pension investments, and that increased worker control of pensions will be necessary in order to secure needed funding for employee-owned ${ }^{15}$ firms.

\section{CONCL.USION: PENSIONS, EMPI OYEE OWNERSHIP, AND INDUSTRIAL DEMOCRACY}

The current transformation of the American economy has resulted in a decline in the material well-being of a majority of workers. A growing number of workers, lahor representatives, and community leaders are advocating employee ownership and worker control of enterprises as one means of reversing this decline. However, these "new" firms have had limited success in redistributing economic. power in the U.S. The following proposals are presented to enliven the debate concerning how to advance industrial democracy in the United States.

As Munnell $(1983: 28,30)$ notes, it is "logical" to increase the input of workers into pension investment decisions because workers share in the consequences of the mismanagement of retirement plans. It is also "reasonable" that a limited percentage of funds be used for investments which benefit current contributors. Such investments could he targeted to specific firms not just for the "double benefit" of preserving local employment while securing retirement income, but also for the triple benefit of expanding worker control of enterprises.

Pension investments might take the form of "industrial mortgages," perhaps being partially guaranteed by various levels of government. Financing could be provided for buyouts of distressed companies which can be viahly operated by employees; for the transfer of a company from a retiring owner to its employees; and to truly democratize the economic development process (Peirce, Hagstrom, and Steinbach, 1979) by establishing a pool of venture capital for the start-up of employee-owned companies. Of course, the commitment of pension monies to buyouts, transfers and start-ups should be accompanied by the requirement of worker control within a specified period (as in the case of Weirton Steel).

Organized labor has been, and will undoubtedly continue to be, at the forefront of the movement to gain control over pensions. However, union leaders have generally resisted worker ownership and control (Slott, 1985), and they may balk at using pension funds for the establishment of employee-owned enterprises.
Worker Ownership and Industrial Democracy

Organized labor's reluctance to embrace worker ownership is understandahle. The substituted for wage and Too often partial ownershe control when they buy out a firm, only to find that they own a company with no future (a form of "lemon socialism").

But as Swinney (1985) and others have pointed out, organized labor is in decline, and union leaders are beginning to see that the current crisis requires decline, and union leaders are beginning to see by labor with a detailed underinnovation. When worker ownership is initiated by labor with a detailed unders need not be standing of the company and its market, buyouts and transfers need not be a means of coopting workers or of unloading unprofitable companies. Further, means of coopting worke ownership does not render unionism obsolete (Whyte et al., 1983:116$-125)$.

New initiatives are needed to meet the challenges of managing economic trans of pension funds to support democratic forms of employee ownership is not only a means to deal with the current restructuring, it also defines ownership is not only a means to deal with the curromic transformation. That goal a possible and desirable end (or goal) of that economic transformation. That goal is the development of economic structures which combine material ahundance with a form of governance compatible with an ideal of, and commitment to, democracy.

\section{FOOTNOTES}

1. Employee ownership and control of enterprises is only one of a number of Eolitical responses to the declining well-being of workers and the deterioration political responses to the declining well-being of workers and the deterioration of community life in the United States. For a more detailed analysis of the political repercussions of deindustrialization and the end of affluence, see Antonio and Knapp (1988).

2. The financial inadequacy of many new johs is revealed by two recent studies. The U.S. Senate's Committee on the Budget (1988) found that over one-half The of the jobs created that almost one-third of the jobs created in the 1980 s were part time, while three-fourths of the people holding those jobs wanted full-time employment.

3. The terms employee and worker are used synonymnusly here. Some of the im important ownership and conil "e discussed below. and nonsupervisory workers in "employee-owned" firms will be discussed below.

4. This is the "extrinsic" reward explanation for greater output in employee-owned firms Others have argued that the "intrinsic" values of work are realized more fully under worker ownership and control of firms, and that this is why productivity is higher. Undoubtedly, both factors come into play. However, produrch indicates that economic returns to employees separate from the basic research indicates that economic returns a very important aspect of the relationship between worker ownership wage are a very important aspect of the relationship between worker 1986). The and higher productivity (Bernstein, 1976:63-68; Rosen et al., 1986). The argument here is that extrinsic rewards are a necessary con

relationship, not that they are a sufficient explanation of it.

5. Employee-owned firms that have publically traded stock are required hy law to pass through full voting rights to employee stock holders. However, only 11 percent of private or "closely held" ESOP companies extend such voting rights to worker-owners (Marsh and McAllister, 1981:593). 
6. There are, of course, noneconomic reasons for advocating industrial democracy. Some writers maintain that the power to alter one's environment and to control day-to-day activities is essential for the psychological and emotional development and well-being of homo faber (Zwerdling, 1980:6). Others consider worker self-management to be a necessary component of a more fully developed democratic society. This is because involvement in work decisions prepares one for participation in the democratic political process, whereas the experience of worker alienation may lead to political apathy (Dahl, 1985:95-98). Also, a rough equality of economic resources helps prevent the subversion of majority rule through the conversion of wealth into inordinate political influence (Dahl, 1979; Bowles and Gintis, 1982)

7. The existing evidence on the power of workplace participation to foster democratic values and increase workers' desire for business control is admittedly mixed. However, as Dahl (1985:98) points out, these results have been obtained from short-term studies of workers who were already rather "fully formed" hy their society. Analyses of Spain's Mondragon system and of Israeli Kihbutzim provide more convincing evidence that the experience of control at work alters values and attitudes in ways which support self-manage-
ment.

8. It is typical for employees to initially own a low percentage of companies, and to be granted modest control. This pattern is due in part to two factors: the reluctance of financial institutions to fund employee ownership plans with majority ownership and any resemblance of worker self-management (Bradley and Gelb, 1985:126); and the hesitancy of managers, especially middle managers, to relinquish authority. Without a dramatic change in the attitudes of managers, and lacking institutionalized financial support for worker ownership such as that in the Mondragon system (see Johnson and Whyte, 1982), there appear to be few alternatives to this gradualist path toward greater worker control.

9. Two elements of the 1984 Act have proved to be strong incentives for employee ownership. First, owners of independent businesses are allowed to defer taxation on the sale of stock to an ESOP or worker cooperative for twelve months. And, if those earnings are reinvested in the stock of other companies in that period, the previous owner will not be taxed until capital gains are made on the sale of the new stock. Second, financial institutions may deduct 50 percent of the interest income they receive either from a loan to a company which contributes an amount of stock equal to the loan to an ESOP, or on a loan directly to an ESOP. The first provision encourages the transfer of ownership of private firms to worker-owners. The second provision increases the availability of finance capital to fund employee ownership plans.

10. Drucker's contention that socialism has been established in the United States was derided by many observers from across the political spectrum. One of the most succinct criticisms came from James Henry who commented in Working Papers: "Perhaps the sole point on which socialist writers would agree is that the transfer of economic ownership to workers, the state or anyone else is by itself irrelevant, and is at best a means to an end. That end is not ownership but control: the extension of democracy to the production process and the elimination of artificial inequality" (in Rifkin and Barber, 1978:11-12).
11. The flip side to the issue of who should control pensions is the question of who is controlled by pensions. Historically, pensions were estahlished as a means of controlling the nascent industrial proletariat (Stnne, 1974). Today, pensions remain an important tool for managing the labor force by discouraging or encouraging turnover, and by influencing worker effort (Lazear, 1985; Viscusi, 1985; Wise, 1985).

12. It is also important that institutional investors vote (pension-owned) shares in a manner which suites corporate customers. Heard (1987:91-94) documents how some companies manipulate the proxy voting of institutional pension fund managers by threatening to sever business ties (remove deposits or change insurance underwriters).

13. Conflicts of interest in self-managed funds would still arise, hut they would be among various plan participants. Present contributors may want to increase investments that secure their johs, while current pensioners may find those investments a threat to the level and safety of their retirement incomes. But these problems are more manageable than institutional conflicts because of broader participation in investment decisions, and because a number of "hybrid" plans combining job-securing investments with pension guarantee provisions already exist (see for example, the plan of Up-Right Inc. in Quarrey et al., 1986:101-107).

14. The evidence from public pension funds also shows that "social" or "alternative" investing need not entail a sacrifice of retirement benefit level or security (La Follette, 1982; Campbell and Josephson, 1983).

15. There are two legal impediments to the democratic management of pension funds and multiple benefit investing. Self-management of union funds is blocked by the Taft-Hartley provision preventing organized labor from exercising more than 50 percent control over pensions. Second, some "alternative" invesiments could be nullified by narrow interpretations of ERISA's exclusive benefit rule. At present, trustees may consider "social" benefits when making investment decisions within ERISA's general guidelines. As the Department of Labor administrator of ERISA noted in the early 1980s, "ERISA provides sufficient flexihility to permit consideration of incidental features of investments which are equal in ezonomic terms. If plan officials are to be in a position to act on the basis of the perceived social benefit features of investments, it will be possible under ERISA" (in Barber, 1982:60). These legal barriers will have to be dealt with if worker control of pension funds is to significantly advanced.

\section{REFERENCES}

Anderson, Jack and Joseph Spear

1988 "Congress' Decision on Insurance May Affect Millions of Americans." Lawrence Joumal World. (January 9):5A.

Antonio, Robert J. and Tim Knapp

1988 "Democracy and Abundance: the Declining Middle and Post-Liberal Politics." Telos 76 (Summer):93-114.

\section{Barber, Randy}

1982 "Pension Funds in the United States: Issues of Investment and Control." Economic and Industrial Democracy 3:31-73. 
Berman, Katrina V.

1982 "The Worker-Owned Plywood Conpertives." Pp. 161-175 in Frank l.indenfeld and Joyce Rothschild-Whitt (eds.), Workplace Democracy and Social Change. Boston: Porter Sargent.

Bernstein, Paul

1976 Workplace Democratization: Its Internal Dynamics. Kent, OH: Kent State University Press.

Bluestone, Barry and Bennett Harrison

1982 The Deindustrialization of America. New York: Basic Books.

1986 "The Great American Job Machine." Washington, DC: The Joint Economic Committee of Congress.

Blumberg, Paul

1968 Industrial Democracy: The Sociology of Participation. London: Constahle.

Bowles, Samuel and Herbert Gintis

1982 "The Crisis of Liheral Democratic Capitalism: The Case of the United States." Politics and Society 11:51-94.

Bowles, Samuel, David M. Gordon, and Thomas E. Weisskopf

1984 Bcyond the Waste Land: A Democratic Allemative to Economic Decline Garden City, NY: Anchor Books.

Bradley, Keith and Alan Gelb

1985 "Employee Buyouts of Troubled Companies." Harvard Business Review 63 (September/October):121-130.

Brownstein, Ronald

1984 "Pension Managers Terminate Retirees' Plans, Then Grab Surplus Assets." National Joumal (March 24):566-569.

Bureau of Labor Statistics

1985 Employment, Hours, and Earnings, United States, 1909-84. Washington, DC: U.S. Government Printing Office.

1987 Supplement to Employment and Eamings (July). Washington, DC: U.S Government Printing Office.

1988 Employment and Eamings (January). Washingtion, DC: U.S. Government Printing $\Theta$ ffice

Bureau of the Census

1985 Money Income of Households," Families and Persons in the Uniled States: 1984. Current Population Report 151. Washington, DC: U.S. Government Printing Office.

1987 Money Income and Poverty Statts of Families and Persons in the United Slates: 1986. Current Population Report 157. Washington, DC: U.S. Government Printing Office.

Business Week

1985 "ESOPs: Revolution or Ripoff?" (April 15):94-108.

Campbell, Beverly Ross and William Josephson

1983 "Public Pension Trustees' Pursuit of Social Goals." Washington University Joumal of Urban and Contemporary Law 24:43-120.

Carnoy, Martin and Derek Shearer

1980 Economic Democracy: The Challenge of the 1980s. Armonk, NY: M.E. Sharpe.
1983 A New Social Contract: The Economy and Govemment After Reagan. New York: Harper \& Row.

Chamber of Commerce of the United States.

19851984 Employee Benefits. Washington, DC: Research Department.

Compa, Lance

1987 "So We Have More Jobs - Low-Paid, Part-Time Ones." Washington Post (March 15):C1-C2.

Conte, Michael, Arnold Tannenbaum, and Donna McCulloch

1981 Employee Ownership. Ann Arbor, MI: Survey Research Center, Institute for Social Research.

Corrigan, Richard

1983 "Pension Funds Attracting Interest As Source for Unconventional Investments." National Joumal (November 12):2367-2370.

Currie, Elliott, Robert Dunn, and David Fogerty

1985 "The Fading Dream: Economic Crisis and the New Inequality." Pp. 94-113 in Jerome Skolnick and Elliott Currie (eds.), Crisis in American Institutions. Boston: Little Brown.

Dahl, Robert

1979 "On Removing Certain Impediments to Democracy in the United States." Political Science Quarterly 92 (Spring):1-20.

1985 A Preface to Economic Democracy. Berkeley, CA: University of California Press.

DeWitt, Sherri

1980 Worker Participation and the Crisis of Liberal Democracy. Boulder, CO: Westview Press.

Drucker, Peter

1976 The Unseen Revolution: How Pension Fund Socialism Came to America. New York: Harper \& Row.

Ellerman, David

1985 The Democratic ESOP. Summerville, MA: Industrial Cooperative Association.

Gordon, David M., Richard Edwards, and Michael Reich

1982 Segmented Work, Divided Workers: The Historical Transformation of Labor in the United States. Cambridge: Cambridge University Press.

Harris, Candee

1984 "The Magnitude of Job Ioss from Plant Closings and the Generation of Replacement Jobs." The Annals of the American Academy of Political and Social Science 475 (September):15-27.

Heard, James E.

1987 "Pension Funds and Contests for Corporate Control." Califomia Management Review 29 (Winter):89-100.

Horvat, Branko

1982 The Political Economy of Socialism: A Marxist - Social Theory. Armonk, NY: M.E. Sharpe.

Jacobson, Louis and Janet Thomason

1979 "Earnings Loss Due to Displacement." Alexandria VA: Center for Naval Analysis. 
Jaffe, David

1986 "The Political Economy of Job Loss in the United States, 1970-1980." Social Prohlems 33 (April):297-318.

Johnson, Ana Gutierrez and William Foote Whyte

1982 "The Mondragon System of Worker Production Cooperatives." Pp. 177-197 in Frank Lindenfeld and Joyce Rothschild-Whitt (eds.), Workplace Democracy and Social Change. Boston: Porter Sargent.

Jones, Derek C. and Jan Svejnar

1982 Participatory and Self-Managed Firms: Evaluating Economic Performance. Lexington, MA: D.C. Heath.

Knapp, Tim

1988a "The Declining Middle Class in an Age of Deindustrialization." Research in Inequality and Social Conflict 2 (forthcoming).

1988b"Hierarchies and Control: A New Interpretation and Reevaluation of Oliver Williamson's 'Markets and Hierarchies' Story." The Sociological Quarterly (forthcoming).

Kosterlitz, Julie

1987 "Promises to Keep." National Journal (August 29):2138-2144.

Kuttner, Robert

1987 "Worker Ownership: A Commitment That's More Often A Con." Business Woek (July 6):16.

La Follette, Cameron

1982 "Public Pension Funds Being Channeled Into I ocal Economic Development." National Joumal (August 21):1466-1469.

Lazear, Edward P.

1985 "Incentive Effects of Pensions." Pp. 253-278 in David Wise (ed.), Pcnsions., Labor, and Individual Choice. Chicago: University of Chicago Press.

Levin, Henry

1982 "Issues in Assessing the Comparative Productivity of Worker-Managed and Participatory Firms in Capitalist Societies." Pp. 45-64 in Derek Jones and Jan Svejnar (eds.), Participatory and Self-Managed Firms. lexington, MA: Lexington Books.

Lichtenstcin, Peter M.

1986 "The U.S. Experience With Worker Cooperation." The Social Science Joumal 23 (January): 1-15.

Lindenfield, Frank and Joyce Rothschild-Witt (eds.)

1982 Workplace Democracy and Social Change. Boston: Porter Sargent.

Marsh, Thomas A. and Dale E. McAllister

1981 "ESOP Tables: A Survey of Companies with Employee Stock Option Plans." The Joumal of Corporation Law 6 (Spring):551-623.

\section{Mason, Ronald M.}

1982 Participalory and Workplace Democracy. Carbondale, IL: Southern Illinois University Press.

Munnel, Alicia

1983 "Who Should Manage the Assets of Collectively Bargained Pension Plans?" New England Economic Review (July/August):18-30.
Owens, Thomas R. and Marilyn Clark

1984 "Joh Loss and its Effects on Dislocated Workers and Their Families." Portland, OR: Education and Work Program, Northwest Regional Educational Laboratory.

Pateman, Carole

1970 Participation and Democratic Theory. Cambridge: Cambridge University Press.

Peet, Richard

1984 "Class Struggle, the Relocation of Employment, and Economic Crisis." Science and Society 48 (Spring):38-51.

Peirce, Neal R., Jerry Hagstrom, and Carol Steinbach

1979 Democratizing the Development Process. Washington, DC: The Council of State Planning Agencies.

Quarrey, Michael, Joseph Blasi, and Corey Rosen

1986 Taking Stock: Employee Ownership at Work. Cambridge, MA: Ballinger.

Rifkin, Jeremy and Randy Barber

1978 The North Will Rise Again: Pensions, Politics and Power in the 1980s. Boston: Beacon Press.

Rosen, Corey and Katherine Klein

1983 "Job-Creating Performance of Employee-Owned Firms." Monthly Labor Revicw 106 (August):15-19.

Rosen, Corey, Katherine Klein, and Karen M. Young

1986 Employee Ownership in America: The Equity Solution. Lexington, MA: D.C. Heath.

Russell, Raymond

1985 Sharing Ownership in the Workplace. Albany, NY: State University of New York Press.

Sease, Douglas $\mathbf{R}$.

1985 "ESOPs Weren't Meant to Be Bailouts." The Wall Street Joumal (Decemher 2):20.

Sheets, Robert G., Russell Smith, and Kenneth Voytek

1985 "Corporate Disinvestment and Metropolitan Manufacturing Job Loss." Social Science Quarterly 66:218-226.

Slott, Mike

1985 "The Case Against Worker Ownership." Mullinational Monitor 6 (November 30):1-4.

Stemnock, Suzan K.

1987 Pension Facts: 1087. Washington, DC: Information Department, American Council of Life Insurance.

Stillman, Don

1978 "The Devastating Impact of Plant Relocations." Working Papers for a New Society 6 (July/August):42-53.

Stone, Katherine

1974 "The Origins of Job Structures in the Steel Industry." Review of Radical Political Economics 6 (Summer):61-97.

\section{Swinney, Dan}

1985 "Worker Ownership: A Tactic For Labor." Multinational Monilor 6 (November 30):4-6. 


\section{Mid-American Review of Sociology}

Tannenbaum, Arnold, Harold Cook, and Jack Lohmann

1984 "Research Report: The Relationship of Employee Ownership to the Technological Adaptiveness and Performance of Companies." Unpuhlished paper. Ann Arbor, MI: University of Michigan Survey Research Center, Institute for Social Research.

Viscusi, W. Kip

1985 "The Structure of Uncertainty and the Use of Pensions as a MohilityReduction Device." Pp. 223-248 in David Wise (ed.), Pensions, Labor, and Individual Choice. Chicago: University of Chicago Press.

Wall Street Joumul

1987a "Fading Benefit: Retirement Prospects Grow Bleaker for Many As Job Scene Changes." (August 26): $1+$.

1987b "Bankruptcy Filings in Steel Overwhelm U.S. Pension Insurer." (May, 21):1+.

Whyte, William Foote, Tove Helland Hammer, Christopher Meek, Reed Nelson, and Robert Stern.

1983 Worker Participation and Ownership. Ithica, NY: ILR Press.

Williamson, Oliver E.

1975 Markcts and Hierarchies: Analysis and Antilnust Implications. New York: The Free Press.

Wise, David A.

1985 "Overview." Pp. 1-17 in David Wise (ed.), Pensions, Labor, and Individual Choice. Chicago: University of Chicago Press.

Zwerdling, Daniel

1980 Workplace Democracy. New York: Harper Colophon.

\section{THE EFFECTS OF WORKING NONTRADITIONAL HOURS ON LIFE SATISFAC'TION}

\section{Cleve R. Redmond}

Iowa Slate Universily

Mid-American Review of Sociology, 1988, Vol. XIII, No. 1:21-40

\section{INTRODUCTION}

One of the central features of modern society is the synchronization of activity that permits it 10 operate. As noted by Hawley (1950:288-316) and Moore (1963:117-122), there are well-defined cycles of activity around which our culture is organized. One of the most important of these is the daily husiness cycle about which most of our lives are arranged. It is hypothesized that maintaining nontraditional daily routines will have negative consequences for the individual Due to the low status and income characteristics generally associated with nighttime occupations, lack of access to career-enhancing contacts, isolation from socioemotional support networks, and physical stress from variahle daily routines and rest interruptions, it is believed that nighttime workers will exhibil lower socioeconomic status and lower life satisfaction than persons maintaining traditional daily routines. This research will use data from a national time-use study to focus on the relationship between nighttime employment and life satisfaction.

\section{TIME AS A DIMENSION OF SOCIAL ORGANIZATION}

The importance of time in the organization of society has been recognized by numerous authors. Parsons (1951:302) states, "A society so complex as ours prohahly could not function without relatively rigid time scheduling." The need for scheduling is not unique to modern Western societies. All societies, no matter how primitive, must coordinate the efforts and activities of their memhers in time and space (Zentner, 1966). Human ecologists in particular have had an interest in the interdependence between the temporal and spatial structures of society (EngelFrisch, 1943). Other writers such as Goffman (1959), Schwärtz (1970), and Zerubavel (1979) have focused on the need for periods of social withdrawal and the institutionalization of these periods.

\section{Human Ecology and Temporal Organization}

Human ecology is best known for its focus on the spatial organization of urhan areas, but its basic premises apply to human social systems of all kinds in their respective environments (Hawley, 1981). In processes seen to parallel biological ecology, human populations come to occupy specific niches in their environments through competition and differentiation. Population pressure is often seen as the driving force behind organizational change in a given environment (e.g., Boserup, 1965; Cohen, 1977). As population increases, the demand for needed resources is met by increased differentiation and specialization.

In some respects, human ecology is similar to both functionalism and conflict 